\title{
Comment on Sharma: platelet-rich-plasma injections for chronic planter fasciitis
}

\author{
Ashwani Soni $\cdot$ Sreekanth Reddy Rajoli
}

Received: 9 December 2013 / Accepted: 10 December 2013 / Published online: 3 January 2014

(C) Springer-Verlag Berlin Heidelberg 2014

Dear Editor,

We read the article "Platelet-rich-plasma injections for chronic planter fasciitis" by Martinelli et al. [1] and the comment by Dr. Deepak Sharma [2] with interest. Though the reply by Dr. Martinelli was satisfactory, that inclusion or exclusion of leukocytes in platelet-rich plasma (PRP) is debatable, we would like to add our views in favour of Dr. Martinelli [3].

Dr. Deepak argued that PRP can be more effective in treating planter fasciitis if leucocytes are separated before injection, as leucocytes lead to an inflammatory process. However, planter fasciitis is a degenerative tissue condition rather than inflammatory [4]. Lemont et al. [5] reported that chronic planter fasciitis is a degenerative condition in which normal fascia tissue is replaced by angiofibroblastic hyperplastic tissue and histology of chronic planter fasciitis is devoid of any inflammatory cell invasion.
Conflict of Interest None

\section{References}

1. Martinelli N, Marinozzi A, Carni S, Trovato U, Bianchi A, Denaro V (2013) Platelet-rich plasma injections for chronic planter fasciitis. Int Orthop 37:839-842

2. Sharma D (2013) Platelet-rich-plasma injections for chronic planter fasciitis. Int Orthop 37:2543

3. Martinelli N (2013) Reply to letter to the editor: platelet-rich plasma injections for chronic plantar fasciitis. Int Orthop. 11 October [Epub ahead of print]. doi:10.1007/s00264-013-2130-z.

4. Buchbinder R (2004) Clinical practice. Plantar fasciitis. N Engl J Med 350:2159-2166

5. Lemont H, Ammirati K, Usen N (2003) Plantar fasciitis: a degenerative process (fasciosis) without inflammation. J Am Podiatr Med Assoc 93:234-237

A. Soni $(\square)$

SGGS Medical College and Hospital, Faridkot 151203, India

e-mail: asoniortho@gmail.com

\section{S. R. Rajoli}

Post Graduate Institute of Medical Education and Research, Chandigarh, India 